\title{
Agnostic investigations
}

\section{Book Title:}

The agnostic inquirer:

Revelation from a

philosophical standpoint

\section{Book Cover:}

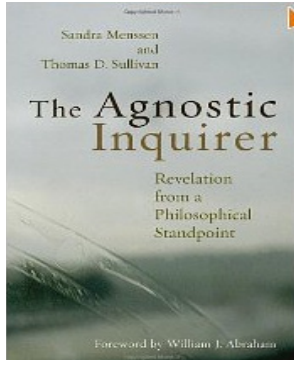

Authors:

Sandra L. Menssen

Thomas D. Sullivan

\section{ISBN:}

978-0-8028-0394-4

\section{Publisher:}

William B. Eerdmans,

Grand Rapids, 2007, pp.

347 , cost unknown

Review Title:

Agnostic investigations

\section{Reviewer:}

Gafie M.J. van Wyk ${ }^{1}$

\section{Affiliation:}

${ }^{1}$ Reformed Theological

College, University of

Pretoria, South Africa

email:

gafievw@mweb.co.za

\section{Postal address:}

Reformed Theological

College, University of

Pretoria, Lynwood Road,

Hatfield 0083, South Afric

How to cite this book review:

Van Wyk, G.M.J., 2010,

'Agnostic investigations',

HTS Teologiese Studies/

Theological Studies 66(1),

Art. \#994, 1 page. DOI:

10.4102/hts.v66i1.994

\section{This review is available}

at:

http://www.hts.org.za

(c) 2010. The Authors.

Licensee: OpenJournals

Publishing. This work

is licensed under the

Creative Commons

Attribution License.
The copy of 'The Agnostic Inquirer' I received for review is neatly printed and bound in soft cover (with a strong, yet flexible back). It comes with a foreword by William J. Abraham, as well as an index of names. The text is well-written and a pleasure to read. If you are looking for a quick and easy 'proof' for revelation or the existence of God, this book will not provide the answers you are looking for. If you are, however, prepared to read well-argued analytical philosophy and are prepared to apply your mind as you are reading, thus entering into your own 'dialogue' with the authors, then this text offers a very fulfilling reading or intellectual experience. The book is a guide to reconsider your position on revelation, whatever it might be. The authors' motto is very much one of 'Know that you do not know and therefore reason with a fare share of skepticism but with an open mind as well'. The book is not only an inquiry into the possibilities of revelation and the existence of God; it is a meta-inquiry into the arguments that support the claims made in support of, or in opposition to revelation or the existence of God.

The authors state their disappointment with the results of natural theology and conclude that

... neither the practitioner of natural theology who explicitly renounces evidence from the content of revelatory claims nor the practitioner who merely ignores it is working with a full database. Both are handicapped ... The general problem is that this kind of natural theology leaves agnostic inquirers with insufficient resources for assessing particular atheistic arguments (such as the argument from evil) and for generating enough evidence to answer the great question of revelation affirmatively.

Later, this view is expressed in even stronger terms:

Standard natural theology lands the agnostic inquirer in a quagmire of theodicy-building without adequate resources: absent appeal to the content of revelatory claims, it is difficult to find the notion of an afterlife plausible; yet most theodicies and defenses of divine goodness rely on that notion.

The authors' proposal to solve the general problem with natural theology as described here, is that an agnostic inquirer ought to consider the question, 'Has a good God revealed anything to us?', early in the process of inquiry, rather than to wait until the task of natural theology has been completed. This proposal is defended and its ramifications are expounded in the book. On page 63 the authors summarise their overarching key argument as follows:

1. If it is not highly unlikely that a world-creator exists, then investigation of the contents of revelatory claims might well show it is probable that a good God exists and has revealed.

2. It is not highly unlikely that a world-creator exists.

3. So, investigation of the content of a revelatory claim might well show it is probable that a good God exists and has revealed.

4. So, a negative conclusion concerning the existence of a good God is not justified unless the content of a reasonable number of leading revelatory claims has been seriously considered.

Messen and Sullivan exercise some initial caution when they conclude:

... the evidence may suggest that a revelation has indeed been given to us. And there well could be reason to accept wholeheartedly a revelatory claim, notwithstanding the less than compelling evidence, if a plausible case for the claim can be made, and one wills to cling to the Good.

However, very soon thereafter, they become much bolder in their claims:

Socrates found evidence in revelatory claims for the existence of good gods. Today we have better materials that appeal to millions the world over: richer revelatory claims that are woven together with time-tested natural theology ... Certainly, as we have emphasized, human errors streak the time-honored revelatory claims, and one must work to cleanse the doctrine of the errors. But one may push through the error. One may ascend from lower to higher.

I concur with Abraham who wrote in the foreword that 'The argument throughout is clear, succinct, and rigorous. It represents the highest standards of analytical philosophy.' The many new readers of this book must judge for themselves whether or not they agree with Abraham as far as the originality and groundbreaking qualities of the authors' argument are concerned. If they do agree, there will be many new converts from the rather large group of agnostic inquirers in the world. 